\title{
HIV Screening: A Review of Nationally Recommended Guidelines and Specific Instances in which HIV Screening is Often Overlooked
}

\author{
Anusha Ganesh, MD
}

\section{INTRODUCTION}

According to the Centers for Disease Control and Prevention (CDC), one in five human immunodeficiency virus (HIV)-infected individuals are currently living without knowledge of their diagnosis. ${ }^{1}$ In 2006, the cost of a rapid HIV test with pre/post-test HIV counseling was anywhere between 48-64 US dollars (USD). The majority of the cost incurred was for HIV counseling, with the cost of the rapid HIV test being between 8-25 USD. ${ }^{2}$ Research looking at the cost-effectiveness of HIV screening shows that it is more cost-effective than routine screening for breast cancer with mammography yearly or even routine screening for diabetes mellitus with a one-time fasting blood glucose. ${ }^{3}$ With the cost of testing reasonably low and prevalence of undiagnosed infection high, why are our rates of HIV screening not maximized?

\section{CASE PRESENTATION}

The following is an example of a patient who would have benefitted from HIV screening as per national guidelines. Ms. C is a 48-year-old female who presented at her gynecologist's office for a routine examination and PAP smear. The patient had never been offered HIV screening in the past. She had a positive HIV test at that visit and was sent to the Infectious Disease clinic for follow-up care. Ms. C denied any active symptoms. Her past medical and surgical history included syphilis, treated with a short course of penicillin $G$, lower back pain, depression, hypothyroidism, gastroesophageal reflux disease (GERD), asthma, tubal ligation, and lipomectomy. She has had multiple Emergency Department (ED) visits in the last three years for various unrelated complaints. Yearly mammograms had been performed for health maintenance and were all within normal limits. She denied history of tuberculosis, pneumonia, or other opportunistic infections. Her social history was positive for a history of non-intravenous drug use in the past and tobacco abuse. She had no recent travel and no current HIV risks or exposures. She has been married for twenty years and stated that she was sexually active and monogamous with her husband. Her vital signs were within normal limits, and there were no abnormalities noted on physical exam.

Based on national guidelines, her positive HIV enzyme immunoassay (EIA) screen was followed by a confirmatory HIV Western Blot. ${ }^{4}$ Her baseline HIV viral load was 1090 copies/mL, and her CD4 count was 230 cells/ $\mu \mathrm{L}$. Although this patient had been treated in the ED numerous times, she remained compliant with health maintenance and had surgical procedures. However, she had never been screened for HIV. Screening for HIV at any of these points in time may have led to earlier diagnosis and treatment.

Broad screening is important, as earlier treatment of HIV has been studied compared to deferred treatment and has been shown to increase survival. ${ }^{5}$ A study compared the risk of death in patients who were started on anti-retrovirals at a higher vs. lower CD4 counts. Those started with the higher CD4 count had improved outcomes with a reduction in number of deaths. Studies have also shown that the risk of transmission of HIV is directly related to viral load, which can be treated if addressed sooner. ${ }^{6}$ The patients who are generally screened are "high risk" patients, such as people who engage in sex without protection, sharing of drug-use equipment, occupational hazards, men who have sex with men, and youths.

This paper will review the current HIV screening guidelines from multiple national organizations (Table 1), which emphasize the importance of screening those individuals who are not necessarily "high risk". 
Table 1: HIV Screening Recommendations

\begin{tabular}{|c|c|c|}
\hline Organization & Screening recommendations & Notes \\
\hline $\mathrm{CDC}^{15}$ & $\begin{array}{l}\text { anyone ages } 13-64 \text { regardless of risk } \\
\text { high risk patients annually } \\
\text { all pregnant women } \\
\text { repeat in third trimester for all high } \\
\text { risk pregnant women } \\
\text { infants exposed in utero } \\
\text { victims of sexual assault }\end{array}$ & $\begin{array}{l}\text { opt out method: allow patient to decline } \\
\text { preventative counseling for HIV not required } \\
\text { written consent not required }\end{array}$ \\
\hline $\begin{array}{l}\text { United States Preventative } \\
\text { Services Task Force } \\
{\text { (USPSTF })^{16}}\end{array}$ & $\begin{array}{l}\text { anyone ages } 15-6 \\
\text { younger adolescents and older } \\
\text { adults who are at risk } \\
\text { all pregnant women, including } \\
\text { those who present in labor }\end{array}$ & \\
\hline $\begin{array}{l}\text { American College of } \\
\text { Physicians (ACP) }{ }^{17}\end{array}$ & $\begin{array}{l}\text { all patients once, more often for } \\
\text { those "at risk" }\end{array}$ & $\begin{array}{l}\text { "at risk": shared injection drug use, blood transfusion } \\
\text { between 1978-1985, unprotected sex with multiple } \\
\text { partners, having an STD }\end{array}$ \\
\hline $\begin{array}{l}\text { American Academy of HIV } \\
\text { Medicine (AAHIVM) }{ }^{18}\end{array}$ & $\begin{array}{l}\text { all adults over } 15 \\
\text { all adults over } 65 \text { (aren't these the } \\
\text { same thing? }\end{array}$ & opt out testing \\
\hline $\begin{array}{l}\text { American College of } \\
\text { Gynecology (ACOG) }{ }^{19}\end{array}$ & $\begin{array}{l}\text { all women between } 19 \text { and } 64 \\
\text { women with risk factors outside } \\
\text { that age range }\end{array}$ & opt out testing \\
\hline
\end{tabular}

\section{DISCUSSION Inpatient}

In 2010, a study was conducted at the Veterans Affair Hospital in Washington, D.C. Which looked at the percentage of patients accepting routine HIV screening in the hospital. Until 2010, only those patients who were considered "high risk" were tested. The testing rate increased from $4.25 \%$ (high risk only) in previous years to $23.8 \%$ (all patients offered screening) during this trial. ${ }^{8}$ A similar study performed in New York City in 2005 showed that, of the patients who were asked to participate in HIV testing, there was not a significantly higher percentage who carried traditional risk factors for HIV. The study supported routine, voluntary testing for HIV, as it diagnosed patients who were not identified in the risk-based testing. ${ }^{9}$ The CDC studied physician-referred HIV testing rates compared to HIV testing rates when a "Voluntary HIV Counseling and Testing" (VCT) program was implemented, allowing all patients to be queried about HIV testing. This program tripled the number of patients being tested for HIV daily. ${ }^{10}$ All these studies validate the argument that, if offered routinely, the utilization of inpatient HIV screening would rise significantly, capturing those who may not be routinely followed in a primary care setting.

The Emergency Department has been cited by the CDC as an important location in which patients of a lower socioeconomic status have their first interaction with a physician. The CDC has recommended in its 2001 guidelines that ED-based HIV testing and counseling should be more widely implemented.11 In one study, targeted screening was studied in a Midwestern, urban teaching hospital to determine the cost-benefit and higher true positive rate of testing of high-risk patients in the ED versus opt-out testing for all patients. The study deemed that, with a wider testing population, more positive tests were identified with a proportional increase in tests offered. There was no benefit to targeted screening, as it did not have a proportionately higher number of positive test results when compared to the large screening group. ${ }^{12}$ 


\section{The Elderly}

It is becoming increasingly important to address HIV screening in the elderly population who are often not considered candidates for testing, as safe sexual practices are not always comfortably discussed in this population. ${ }^{13}$ Among all patients with HIV infection, 37\% are now over the age of fifty. It is estimated that this number will increase to $50 \%$ by the year $2015 .{ }^{13}$ Patients who are diagnosed at a later age will be more likely to experience increased morbidity and mortality and a higher risk of opportunistic infections. ${ }^{13}$ The main risk factor for HIV acquisition in the elderly is heterosexual intercourse. ${ }^{13}$ The reasons for missed opportunities for HIV screening in this population include lack of knowledge of HIV in older patients, underestimating the risk of contracting HIV, and the social stigma associated with HIV. ${ }^{13}$

\section{Low Risk Factor Population}

In 2006, the Institute of Medicine (IOM) studied offers of HIV screening to patients in the state of Virginia. IOM discovered that primary care physicians, although aware of the guidelines, were more hesitant to implement screening in all patients because they weren't comfortable treating patients who had a positive test result. ${ }^{14}$ HIV testing also required more staffing and education to providers in the clinic. Further complicating this was the difficult conversation with individuals, such as our patient, who are not considered to be "high risk". ${ }^{14}$ Nonetheless, the evidence shows that even in low risk populations, it is vital for primary care providers to address the importance of a one-time HIV screening to ensure the patient's health and safety.

\section{KEY POINTS}

The three main categories of patients who are often missed for HIV testing include patients in the acute care setting, elderly individuals, and the low-risk population. They should all be offered opt-out testing by their primary physician or hospitalist, as per national guidelines. It is a low-cost test, with an extremely high benefit value. All major national health organizations are recommending that physicians offer one time HIV screening in all patients regardless of age, gender, or perceived risk status.

\section{REFERENCES}

1. Chen M, Rhodes $\mathrm{PH}$, Hall $\mathrm{HI}$, et al. Prevalance of undiagnosed HIV infection among persons aged $>13$ years - National HIV Surveillance System, United States, 2005-2008. Centers for Disease Control and Prevention (CDC). MMWR 2012; 61(02): 57-64.

2. Pinkerton S, Bogart L, Devery $H$, et al. Cost of rapid HIV testing at 45 U.S. hospitals. AIDS Patient Care and STDS. 2010; 24(7): 409-413.

3. Walensky R, Freedberg K, Weinstein MC, et al. Cost-effectiveness of HIV testing and treatment in the United States. Clin Infect Dis. 2007; 45(4): S248-S254.

4. Aberg JA, Kaplan JE, Libman $\mathrm{H}$, et al. Primary care guidelines for the management of persons infected with human immunodeficiency virus: 2009 update by the HIV Medicine Association of the Infectious Diseases Society of America. CID. 2009; 49: 651-681.

5. Mari K, Stephen G, Alison A, et al. Effect of early versus deferred antiretroviral therapy for HIV on survival. N Engl J Med. 2009; 360 (18): 1815-1826.

6. Quinn TC, Wawer MJ, Sewankambo N, et al. Viral load and heterosexual transmission of human immunodeficiency virus type 1. Rakai Project Study Group. N Engl J Med. 2000; 342(13): 921-929. 7)

7. Quick facts about HIV transmission. National Institute of Allergy and Infectious Diseases, 2009. (Accessed November 1, 2013, at http://www.niaid.nih.gov/topics/hivaids/understanding/pages/ riskfactors.aspx.)

8. Siegel M, Kennedy $K$, Rexroth $K$, et al. Better but not ideal acceptance of routine inpatient HIV point-of-care testing among veterans in a high prevalence a.rea. J Acquir Immune Defic Syndr 2010; 55(2): 205-210

9. Charu J, Jane SJ, Richard M, et al. Acceptance of rapid HIV testing among medical inpatients in New York City. AIDS Patient Care and STDS. 2008; 22(8): 657-662.

10. Greenwald JL, Hall J, Skolnik PR. Approaching the CDC's guidelines on the HIV testing of inpatients: physician-referral versus noreferral-based testing. AIDS Patient Care STDS. 2006; 20(5): 311-317

11. Richard R. Current Centers for Disease Control and Prevention guidelines for HIV counseling, testing, and referral: critical role of and call to action of emergency physicians. Ann Emerg Med. 2004; 44(1): 31-42.

12. Lyons MS, Lindsell CJ, Ruffner AH, et al. Randomized comparison of universal and targeted HIV screening in the Emergency Department. J Acquir Immune Defic Syndr. 2013; 64(3): 315-323.

13. Abras CK, Appelbaum JS, Boyd CM, et al. Recommended treatment strategies for clinicians managing older patients with HIV. American Academy of HIV Medicine. 2010; 1-76.

14. Institute of Medicine. HIV Screening and Access to Care. 1st ed. Washington, DC: The National Academies Press; 2011.

15. Branson BM, Handsfield HH, Lampe MA, et al. Revised recommendations for HIV testing of adults, adolescents, and pregnant women in health-care settings. Centers for Disease Control and Prevention (CDC). MMWR Recomm Rep. 2006; 55(RR-14): 1-17

16. Screening for HIV, Topic Page: U.S. Preventive Services Task Force, 2013. (Accessed November 1, 2013, at http://www.uspreventiveservicestaskforce.org/uspstf/uspshivi.htm) 
17. Qaseem A, Snow V, Shekelle P, et al. Screening for HIV in health care settings: a guidances statement from the American College of Physicians and HIV Medicine Association. Annals of Interna Medicine. 2009; 150(2): 125-131

18. Routine HIV Testing. American Academy of HIV Medicine, 2013. (Accessed November 1, 2013, at http://www.aahivm.org/routinehivtesting.)
19. Routine Human Immunodeficiency Virus Screening. ACOG Opinion No 411. American College of Obstetrics and Gynecology 2008. (Accessed November 1, 2013, at http://www.acog.org/ Resources_And_Publications/Committee_Opinions/Committee_ on_Gynecologic_Practice/Routine_Human_Immunodeficiency_ Virus_Screening)

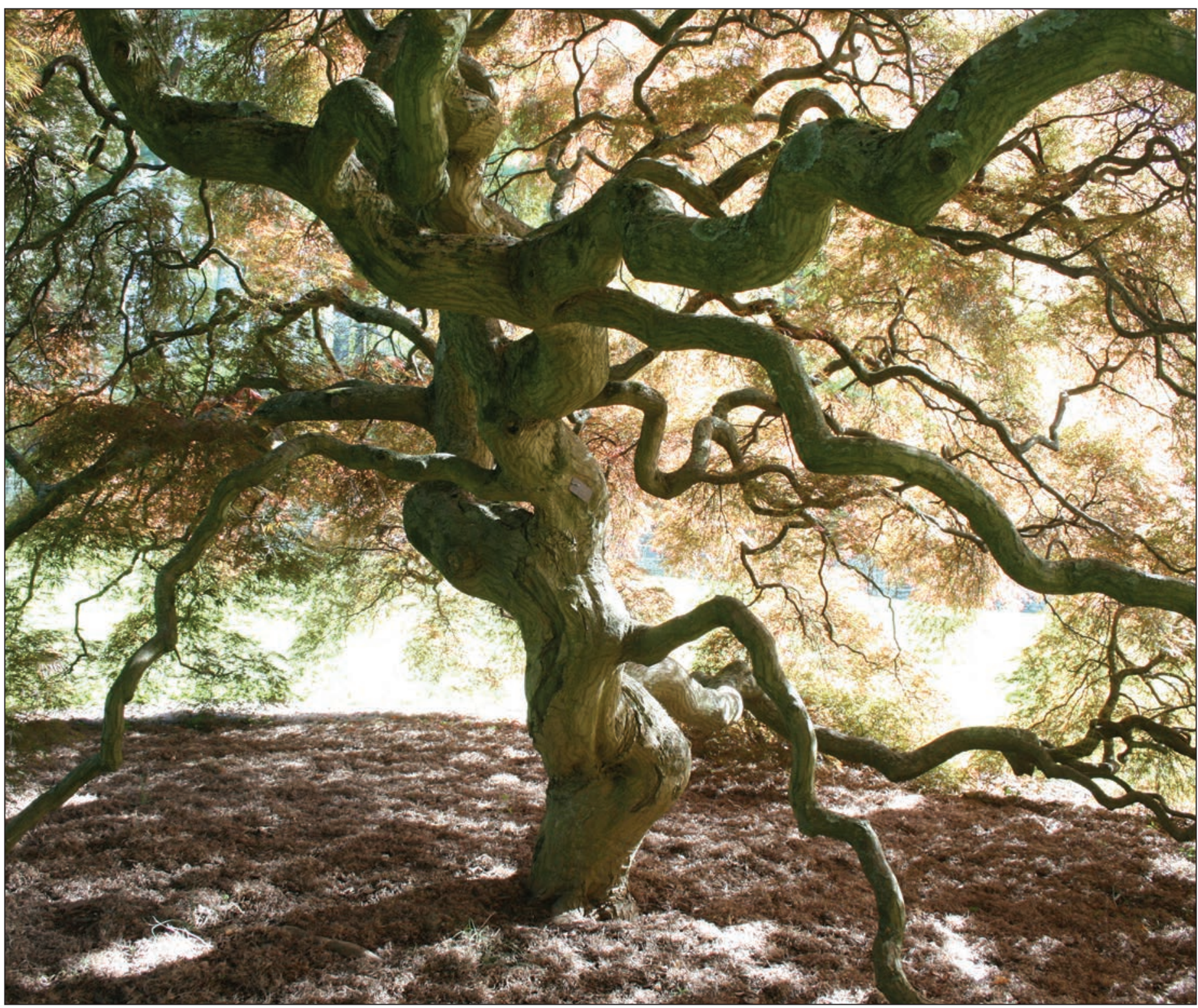

